\title{
Stationarity and Cointegration between Health Care Expenditure and GDP for Jordan
}

\author{
${ }^{1}$ Rasha M.S. Istaiteyeh and ${ }^{2}$ Mohd Tahir Ismail \\ ${ }^{I}$ Department of Economics, Faculty of Economics and Administrative Sciences, \\ The Hashemite University, P.O. Box 330128, Postal Code 13133, Zarqa, Jordan \\ ${ }^{2}$ School of Mathematical Sciences, Universiti Sains Malaysia, Malaysia
}

Article history

Received: 11-06-2016

Revised: 17-01-2017

Accepted: 12-05-2017

Corresponding Author:

Rasha M. S. Istaiteyeh

Department of Economics,

Faculty of Economics and

Administrative Sciences, The

Hashemite University, P.O.

Box 330128, Postal Code

13133, Zarqa, Jordan

E-mail: ristaiteyeh@hu.edu.jo

\begin{abstract}
This paper explores the Granger-causality relationship between real GDP per capita and real health care expenditure per capita for Jordan during 1995 through 2013. The findings point out that the dominant type of Granger-causality is unidirectional. Furthermore, income elasticity of health expenditure is less than 1 , which means that health care is a necessary good in Jordan. To this end, policies must be aimed at raising national income to improve eventually the well-being of the population.
\end{abstract}

Keywords: Health Care Expenditure, Granger Causality, GDP, Jordan

\section{Introduction}

The health care expenditure and Gross Domestic Product (GDP) relationship has been investigated extensively in literature of health economics. The presence of unit roots, co integration and panel unit root tests in the literature provided stimulus in the empirical testing for this relationship. As general notion, a variable is called Granger if a former and a present values are used to predict the former one (Devlin and Hansen, 2001). Therefore, causality between health care expenditure and Gross Domestic Product (GDP) can be in either or both directions. That is, if a significant percentage of change in per capita health care expenditure can be explained by variations in per capita GDP, it is then called direct causality (Erdil and Yetkiner, 2009). Accordingly, to test for the existence of causality requires first to test if present and former values of health care expenditure can be used in forecasting future values for GDP. If two variables were found to Granger cause the other and then a bidirectional Granger causality can be concluded. Attention is also paid in the literature on the concept of health spending elasticity on per capita GDP. The main question is whether health care spending is a necessary or a luxury services (Lago-Peñas et al., 2013). The debate on this relationship was whether income elasticity of health care expenditure is more or less than 1 . If income elasticity is less than one, then health expenditure and income are considered to be inelastic, that is, a necessary good. On the other hand, if income elasticity is more than one, then health care expenditure is considered to be a "luxury" good.

Jordan is an upper middle income country, faced with constraints in natural resources, lack of adequate financial capital, rather investing heavily on its human capital. According to Mushkin, (1962) health is a form of human capital. In addition, the service sector in Jordan comprises 66.3 of the GDP (CIA, 2016). Therefore; any substantial growth of the GDP is dependent on the growth of services. Moreover, Jordan's healthcare sector has been rising in attractiveness with the country being Well known as a leading medical tourism destination which ranked by the World Bank as a top ranking destination in the Arab world and fifth globally (Jordinvest, 2012).

In order to avoid the heterogeneity problem between causal relationships or between data processing, Granger causality test is applied. Therefore, it is the most effective and practical way to test the causality direction between health care spending and GDP. This study aims to supply evidence on the relationship between Jordan's health care expenditure and GDP (on a per capita basis) by employing Granger-causality test.

The rest of the paper is structured as follows. Literature review on causality studies on health care expenditure in relation to GDP are provided in section 2 . Data and methodology adopted are presented in section 3. Section 4 details main results and concluding remarks are presented in the final section. 


\section{Literature Review}

The relationship between health care expenditure and GDP has been the focus of a large scale of literature (Kumar, 2013). Starting with Newhouse (1977) and afterwards in the 1980s studies as in Parkin et al. (1987; Leu, 1986) and in the 1990s as in Barros (1998; Posnett and Hitiris, 1992; Hansen and King, 1996). The literature has shown that the relation between health care expenditure and income can be either direct causation, reverse causation or a bidirectional one (Erdil and Yetkiner, 2009). Studies of the first strand of relationship are found in Erdil and Yetkiner (2009) where in low- and middle-income countries a one-way causality running from (GDP) to health was found and for high-income countries the reverse was found. Kiymaz et al. (2006) indicated a one-way causality from per capita GDP to per capita private health care expenditure. Other studies in this streamline of research are also found in Magazzino and Mele (2012; Jochen and Jan-Egbert, 2014; Samadi and Homaie, 2013).

Akhmat et al. (2014) found that economic growth has significant causal effect on social health indicators in East Asia and Pacific, MENA, South Asia and SubSaharan Africa in the long run term and one of these social health indicators was out-of-pocket health costs. Mehrara and Musai (2011) concluded a strong evident causality from economic growth to health expenditures in oil exporting countries considered in their study. Alternatively, some studies, found significant positive effect of health care spending on economic development. In a way, the increase in health spending is translated into higher labour supply and productivity, which in the end raises output growth. This is often called reverse causation (Erdil and Yetkiner, 2009).

Devlin and Hansen (2001) have tested the association between health care spending and gross domestic product for some of the 20 OECD countries and revealed that for some of the latter countries, health care spending Granger causes GDP and vice versa for other countries. Esteve and Martinez-Zahonero (2007) pointed out to the evidence of a long-run relationship between per capita health spending and GDP per capita in Spain within two structural breaks in 1971 and 1991. Wang (2011) focused on the relation between an increase in health care spending and economic growth and found a direct causation from HCE to GDP. Whereas Dritsakis (2005) confirmed a long- run relationship between health spending and GDP.

The link between health spending and GDP is vital for policy making, as health is considered as an investment in human capital that contributes to economic growth. It is also assumed that high levels of health spending can lead to an increase in output levels, through higher labor supply and productivity (Kumar, 2013).

In general, health status in a country affects its economic growth (dubbed by GDP per capita) through different mechanisms. First, economic growth signals rising per capita income, hence part of this increased income is reflected into consumption of higher quantity of and better quality of nutritious foods. Then, economic growth is fueled by technological progress and part of this progress passes through improvements and advancements in medical sciences (Wang, 2011). In the end, an enhancement in population health enables the country to produce more with given economic resources.

In other stem of studies, bi-directional causality between health and income exits. That is healthier people can work harder Amiri and Ventelou (2012) and improvements in income can lead to higher consumption of healthy food, of healthier behavior traits and of medical follow ups and examinations. Abbas and Hiemenz (2013) demonstrated a two-way causality between income and health care spending for Pakistan during the period (1972-2009). Kumar (2013) revealed a bi-directional causality between health spending and gross domestic product in 10 OECD countries over the period (1960-2007), whereas Amiri and Ventelou (2012) observed for a 20 OECD countries through the period (1970-2009) a bidirectional granger causality between GDP and healthcare expenditure.

Summary on literature review of different causality studies between health care expenditures and income are presented in Table 1.

Table 1. Review of causality studies between HCE and GDP

\begin{tabular}{|c|c|c|c|c|c|}
\hline Study & Aim of study & Country (Time line) & Variables used & Methodology & Conclusion \\
\hline \multicolumn{6}{|l|}{ From GDP to HCE } \\
\hline $\begin{array}{l}\text { Erdil and } \\
\text { Yetkiner (2009) }\end{array}$ & $\begin{array}{l}\text { Tested bidirectional } \\
\text { causality between real per } \\
\text { capita GDP and real per } \\
\text { capita health expenditures. }\end{array}$ & $\begin{array}{l}19 \text { Low-income } \\
22 \text { Lower middle-income } \\
10 \text { Upper middle income } \\
24 \text { High-income countries } \\
(1990-2000)\end{array}$ & $\begin{array}{l}\text { 1. Real per capita GDP } \\
\text { 2.Real per capita health } \\
\text { expenditures. }\end{array}$ & $\begin{array}{l}\text { Macro panel data } \\
\text { set with VAR } \\
\text { representation }\end{array}$ & $\begin{array}{l}\text { 1. One-way causality } \\
\text { runs from GDP to health in } \\
\text { low- and middle-income } \\
\text { countries, while the reverse is } \\
\text { true for high-income countries. }\end{array}$ \\
\hline $\begin{array}{l}\text { Kiymaz et al. } \\
(2006)\end{array}$ & $\begin{array}{l}\text { Examined long-run relation } \\
\text { ship between per capita } \\
\text { private, public and total } \\
\text { health care expenditure } \\
\text { and per capita gross } \\
\text { domestic product and } \\
\text { population growth. }\end{array}$ & $\begin{array}{l}\text { Turkey } \\
(1984-1998)\end{array}$ & $\begin{array}{l}\text { 1.Per capita private } \\
\text { health care expenditure. } \\
\text { 2.Per capita public } \\
\text { health care expenditure. } \\
\text { 4.GDP per capita } \\
\text { 5. Population growth rate. }\end{array}$ & Cointegration & $\begin{array}{l}\text { 1. One-way causality } \\
\text { from per capita GDP to } \\
\text { various definitions of } \\
\text { health care expenses. }\end{array}$ \\
\hline $\begin{array}{l}\text { Jochen and } \\
\text { Jan-Egbert (2014) }\end{array}$ & $\begin{array}{l}\text { Disclosed strong } \\
\text { explanatory variables } \\
\text { for health care } \\
\text { expenditure growth. }\end{array}$ & $\begin{array}{l}33 \text { OECD countries } \\
(1970-2010)\end{array}$ & $\begin{array}{l}\text { Macroeconomic and } \\
\text { institutional variables of } \\
\text { health care expenditure. }\end{array}$ & $\begin{array}{l}\text { Extreme Bounds } \\
\text { Analysis (EBA) }\end{array}$ & $\begin{array}{l}\text { 1.GDP growth } \\
\text { 2.Baumol's 'cost disease' is } \\
\text { statistically significant } \\
\text { determinants of health care } \\
\text { expenditure growth. }\end{array}$ \\
\hline
\end{tabular}




\begin{tabular}{|c|c|c|c|c|c|}
\hline $\begin{array}{l}\text { Samadi and Rad } \\
\text { (2013) }\end{array}$ & $\begin{array}{l}\text { Surveyed determinants } \\
\text { of health expenditures. }\end{array}$ & $\begin{array}{l}\text { Economic cooperation } \\
\text { Organization countries } \\
\text { Armenia Azerbaijan Iran, } \\
\text { Kazakhstan, Kyrgyzstan } \\
\text { Pakistan, Tajikistan, } \\
\text { Turkey Turkmenistan } \\
\text { Uzbekistan } \\
(1995-2009)\end{array}$ & $\begin{array}{l}\text { 1. Health care expenditures } \\
\text { per capita at purchasing } \\
\text { power parity. } \\
\text { 2. Gross domestic product } \\
\text { per capita } \\
\text { 3. Population below } \\
\text { 15 years old. } \\
\text { 4, Private healthcare } \\
\text { expenditures to total } \\
\text { healthcare expenditures (in \%). } \\
\text { 5. Number of physicians } \\
\text { per } 1000 \text { people, } \\
\text { 6. People who live in } \\
\text { urban regions to total } \\
\text { population (in \%). }\end{array}$ & $\begin{array}{l}\text { 1. Pesaran cross } \\
\text { sectional dependency } \\
\text { test. } \\
\text { 2. Panel unit root tests. } \\
\text { 3. Westerlund panel } \\
\text { cointegration test } \\
\text { 4. Continuous-updated } \\
\text { fully modified } \\
\text { estimator. } \\
\text { 5. Fixed effects estimator. }\end{array}$ & $\begin{array}{l}\text { 1. Long term relationship } \\
\text { between and GDP per capita, } \\
\text { and health expenditures } \\
\text { per capita. }\end{array}$ \\
\hline $\begin{array}{l}\text { Akhmat et al. } \\
\text { (2014) }\end{array}$ & $\begin{array}{l}\text { Investigated a two-way } \\
\text { statistical relationship } \\
\text { between social health } \\
\text { indicators and economic } \\
\text { growth. }\end{array}$ & $\begin{array}{l}\text { Four regions } \\
\text { East Asia and Pacific } \\
\text { Middle East and } \\
\text { North Africa } \\
\text { South Asia } \\
\text { Sub-Saharan Africa } \\
(1975-2011)\end{array}$ & $\begin{array}{l}\text { Sixteen social indicators: } \\
\text { 1.Infant mortality, } \\
\text { 2. Child abuse. } \\
\text { 3. Child poverty. } \\
\text { 4. Teenage suicide. } \\
\text { 5. Teenagers drug abuse. } \\
\text { 6. High school dropouts. } \\
\text { 7. Unemployment. } \\
\text { 8. Weekly wages. } \\
\text { 9. Health insurance coverage. } \\
\text { 10. Elderly living in poverty } \\
\text { 11. Out-of-pocket health-care } \\
\text { costs among the elderly. } \\
\text { 12. Homicides. } \\
\text { 13. Traffic fatalities } \\
\text { related to alcohol. } \\
\text { 14. Food insecurity. } \\
\text { 15. Affordable housing, } \\
\text { 16. Income inequality. } \\
\text { 17. GDP per capita. }\end{array}$ & $\begin{array}{l}\text { Co-integration } \\
\text { and Granger } \\
\text { causality tests. }\end{array}$ & $\begin{array}{l}\text { 1. Economic growth has long } \\
\text { run casual effect on social } \\
\text { health indicators in all regions. }\end{array}$ \\
\hline $\begin{array}{l}\text { Mehrara and } \\
\text { Musai (2011) }\end{array}$ & $\begin{array}{l}\text { Tested causal relationship } \\
\text { between health } \\
\text { expenditure and GDP. }\end{array}$ & $\begin{array}{l}11 \text { selected oil } \\
\text { exporting countries } \\
\text { Iran Kuwait Saudi Arabia } \\
\text { U.A.E Oman Bahrain } \\
\text { Algeria Nigeria Venezuela } \\
\text { Mexico Ecuador } \\
(1971-2007)\end{array}$ & $\begin{array}{l}\text { 1. Real health expenditure. } \\
\text { 2. Real GDP per capita. } \\
\text { 3. Real oil revenues. }\end{array}$ & $\begin{array}{l}\text { 1. Panel unit root tests. } \\
\text { 2. Panel cointegration } \\
\text { analysis. }\end{array}$ & $\begin{array}{l}\text { 1. Significant causality from } \\
\text { oil revenues (economic } \\
\text { growth) to health expenditure. }\end{array}$ \\
\hline \multicolumn{6}{|l|}{ From HCE to GDP } \\
\hline Wang (2011) & $\begin{array}{l}\text { Explored causality } \\
\text { between increase in } \\
\text { health care expenditure } \\
\text { and economic growth. }\end{array}$ & $\begin{array}{l}31 \text { countries } \\
\text { Belgium Canada Czech } \\
\text { Republic Luxembourg } \\
\text { Denmark Finland France } \\
\text { Iceland Germany Italy } \\
\text { Poland Greece Hungary } \\
\text { Netherlands Norway } \\
\text { Ireland Korea Japan } \\
\text { Mexico New Zealand } \\
\text { Portugal Republic of China } \\
\text { Taiwan Slovak } \\
\text { Republic Spain Sweden } \\
\text { Switzerland Turkey UK US }\end{array}$ & $\begin{array}{l}\text { 1. International total } \\
\text { expenditure on health. } \\
\text { 2. International total } \\
\text { expenditure on personal } \\
\text { health care. } \\
\text { 3. International total } \\
\text { expenditure on health } \\
\text { per capita. } \\
\text { 4. National income (GDP). }\end{array}$ & $\begin{array}{l}\text { 1. Panel regression } \\
\text { analysis. } \\
\text { 2. Quantile regression } \\
\text { analysis. }\end{array}$ & $\begin{array}{l}\text { 1. Health care expenditure } \\
\text { growth will affect } \\
\text { economic growth. }\end{array}$ \\
\hline $\begin{array}{l}\text { Devlin and } \\
\text { Hansen (2001) }\end{array}$ & $\begin{array}{l}\text { Explored relationship } \\
\text { between health care } \\
\text { expenditure and gross } \\
\text { domestic product. }\end{array}$ & $\begin{array}{l}\text { 20 OECD countries } \\
(1960-1987)\end{array}$ & $\begin{array}{l}\text { 1.Per capita health care } \\
\text { expenditure (in real terms) } \\
\text { 2.GDP. }\end{array}$ & Granger causality tests. & $\begin{array}{l}\text { 1. Health care spending } \\
\text { Granger causes GDP. }\end{array}$ \\
\hline Dritsakis (2005) & $\begin{array}{l}\text { Investigated relationship } \\
\text { between health } \\
\text { expenditures and gross } \\
\text { domestic product. }\end{array}$ & $\begin{array}{l}15 \text { member- } \\
\text { countries of EU } \\
(1960-1998)\end{array}$ & $\begin{array}{l}\text { 1. Real health } \\
\text { care expenditures. } \\
\text { 2. Gross domestic product. } \\
\text { 3. Relative prices of health } \\
\text { care expenditure. }\end{array}$ & $\begin{array}{l}\text { 1. Unit root test. } \\
\text { 2. Engel-Granger } \\
\text { and Johansen. } \\
\text { 3. Juselious } \\
\text { cointegration tests. } \\
\text { 4. Error correction model. }\end{array}$ & $\begin{array}{l}\text { 1. Long run relationship } \\
\text { between health expenditures } \\
\text { and gross domestic product. }\end{array}$ \\
\hline $\begin{array}{l}\text { Esteve and } \\
\text { Martinez-Zahonero } \\
(2007)\end{array}$ & $\begin{array}{l}\text { Examined long-run } \\
\text { relationship between } \\
\text { per capita health } \\
\text { expenditures }\end{array}$ & $\begin{array}{l}\text { Spain } \\
(1960-2001)\end{array}$ & $\begin{array}{l}\text { 1. Per capita health } \\
\text { expenditures. } \\
\text { 2. Per capita } \\
\text { national income. }\end{array}$ & $\begin{array}{l}\text { Unit roots } \\
\text { Stock-Watson-Shin } \\
\text { cointegration test. }\end{array}$ & $\begin{array}{l}\text { 1. Long -run relationship } \\
\text { between Health Expenditures } \\
\text { (HE) (on per capital basis) and } \\
\text { national income(per capita) }\end{array}$ \\
\hline \multicolumn{6}{|c|}{ Bi-directional between GDP and HCE } \\
\hline $\begin{array}{l}\text { Abbas and } \\
\text { Hiemenz (2013) }\end{array}$ & $\begin{array}{l}\text { Estimated factors } \\
\text { affecting public } \\
\text { health expenditures }\end{array}$ & $\begin{array}{l}\text { Pakistan } \\
(1972-2009)\end{array}$ & $\begin{array}{l}\text { 1. Real per capita } \\
\text { health care } \\
\text { 2. Demographic, social, } \\
\text { economic and health care } \\
\text { services variables. }\end{array}$ & $\begin{array}{l}\text { Unit root and Johansen } \\
\text { cointegration methods. }\end{array}$ & $\begin{array}{l}\text { A Two-way causality between } \\
\text { income GDP and health care } \\
\text { spending }\end{array}$ \\
\hline Kumar (2013) & $\begin{array}{l}\text { Examined link } \\
\text { between health } \\
\text { spending and GDP. }\end{array}$ & $\begin{array}{l}10 \text { OECD countries } \\
(1960-2007)\end{array}$ & $\begin{array}{l}\text { 1. Real per capita health } \\
\text { spending. } \\
\text { 2. Real per capita GDP. }\end{array}$ & $\begin{array}{l}\text { Systems generalized } \\
\text { method of moments } \\
\text { SGMM. }\end{array}$ & \\
\hline $\begin{array}{l}\text { Amiri and } \\
\text { Ventelou (2012) }\end{array}$ & $\begin{array}{l}\text { Tested causality } \\
\text { between GDP and } \\
\text { health care expenditure. }\end{array}$ & $\begin{array}{l}20 \text { OECD countries } \\
(1970-2009)\end{array}$ & $\begin{array}{l}\text { 1. Real per capita } \\
\text { healthcare expenditure. } \\
\text { 2. Real per capita income. }\end{array}$ & $\begin{array}{l}\text { Modified version of } \\
\text { Granger test. }\end{array}$ & $\begin{array}{l}\text { A bi-directional Granger } \\
\text { causality between GDP and } \\
\text { health care expenditure. }\end{array}$ \\
\hline
\end{tabular}




\section{Data and Methodology}

This study attempts to identify the causality relationship between GDP and health expenditures in Jordan. The data used in this study are Per Capita Health Care Expenditures (PCHCE) and per capita GDP (PCGDP). Total health expenditure includes the sum of public and private health expenditures. It contains the provision of health services (both preventive and curative), family planning activities, nutrition activities and emergency aid designated for health, but does not include availability of water and sanitation. The yearly data from 1995 until 2014 of PCHCE (in constant 2011 US\$) and PCGDP (in constant 2005 US\$) are compiled from the World Bank.

The time series plots of PCHCE and PCGDP are depicted in Fig. 1, while Table 2 shows descriptive statistics of these two series. As seen in Fig. 1, the PCGDP was having an upward trend through the years from 1995 to 2013. However, PCHCE is increasing steadily from 1995 until 2011, but dropped dramatically from 2012 until 2014. Overall from Table 2 both series have leptokurtic peak and lack of symmetry which show non normality.

In order to model the bidirectional relationship, two tests need to be conducted. The two tests are stationary test and the cointegration test. Commonly unit root test likes the ADF and PP tests will be used to investigate the stationarity of a series. However, in this study, because of the small sample the p-value from the unit root test are unreliable. Therefore, the KPSS test by Kwiatkowski et al. (1992) will be applied with the null hypothesis of stationary versus non-stationary. The KPSS test specification is given in Equation 1:

$$
Y_{t}=\beta t+\eta_{t}+a_{t}
$$

where, $Y_{t}$ represent the two series, PCHCE and PCGDP, $\eta_{t}=\eta_{t-1}+\mu, \mu$ are i.i.d. with mean 0 and variance $\sigma_{\mu}^{2}$ and $a_{t}$ are i.i.d. with a mean 0 and a variance $\sigma_{a}^{2}=1$. Rejecting or accepting the null hypothesis is based on the value of $\sigma_{\mu}^{2}$ where if $\sigma_{\mu}^{2} \geq 0$ the null hypothesis cannot be rejected. Results in Table 3 indicate both series are non-stationary at the level data where the null hypothesis is rejected, whereas both series became stationary after first differences where the null hypothesis is not rejected. This result indicates both series are stationary at the same level, which is integrated. Hence, the assumption for further test and research of long term relationships between specified variables is met.

Next, cointegration test is carried out to investigate if the two series are cointegrated or not. Cointegration test helps to specify whether there is any relationship between the series in the long run. Vector Autoregression (VAR) analysis will be performed at first difference if the variables under study are cointegrated, otherwise, Vector Error Correction Model (VECM) analysis will be carried out at the level. In this study, the Johansen test going to be executed. The Johansen test is based on two test statistics, the Trace statistic and Max-eigen statistic (Johansen and Juselius, 1990; Johansen, 1988).

The cointegration test only provides information regarding the existence of causality between a two series, but it does not indicate the direction of the causality relationship. Hence, the Granger causality test needs to be run to capture the direction of causal relationships. Engle and Granger (1987) showed that if the two series are cointegrated, therefore the vectorerror correction model for the PCGDP and PCHCE series are given as in following Equation 2 and 3:

$$
\begin{aligned}
& \triangle \text { PCHEA }_{t}=\alpha+\sum_{i=1}^{k} \beta_{i} \Delta \text { PCHEA }_{t-1}+\sum_{i=1}^{k} \gamma_{i} \Delta P C G D P_{t-i}+\delta \varepsilon_{t-1}+\mu_{t} \\
& \triangle P C G D P_{t}=\alpha+\sum_{i=1}^{k} \beta_{i} \Delta P C G D P_{t-1}+\sum_{i=1}^{k} \gamma_{i} \Delta P C H E A_{t-i}+\delta \varepsilon_{t-1}+\mu_{t}
\end{aligned}
$$

where, $\varepsilon_{t-1}$ refers to the error correction term derived from long-run cointegrating relationship.

From previous section, KPSS test specify that both series, PCHCE and PCGDP are of order 1 of 1 st difference stationary.Therefore, the Johansen cointegration test is conducted to test whether the two series are co-integrated. From Table 4, Trace statistics show that the two series, i.e., PCHCE and PCGDP, have one equation for cointegrating $\left(\mathrm{H}_{0}: r=0\right.$ is rejected at $1 \%$ level). However, Max-eigen statistics display that both series are not cointegrated. Usually in cases of contradicting results between these two tests, Trace statistics is preferred. The optimum lag length for Johansen cointegration test is based on AIC at its minimum where the value is 2 .

Based on the result of Trace statistics, both series are cointegrated, hence the analysis proceed with modelling the relationships by utilizing Vector Error Correction Model (VECM). Table 5 tabulated the estimation VECM while Table 6 presented several specification tests on the residuals. All the specification tests for the vector error correction model (testing for the presence of serial correlation and heteroskedasticity) tend to indicate that the model is well-specified. In addition, it can be seen form Table 5 that the estimation VECM includes the cointegration relation (denoted by Coint Equation 1) built into the specification so that relationship between the variables are not spurious and indicates that there is a theoretical association within the variables. Moreover, this will restrict the long-run behaviour of the endogenous variables to converge to their cointegrating relationships while allowing for short-run adjustment dynamics. 
PCGDP

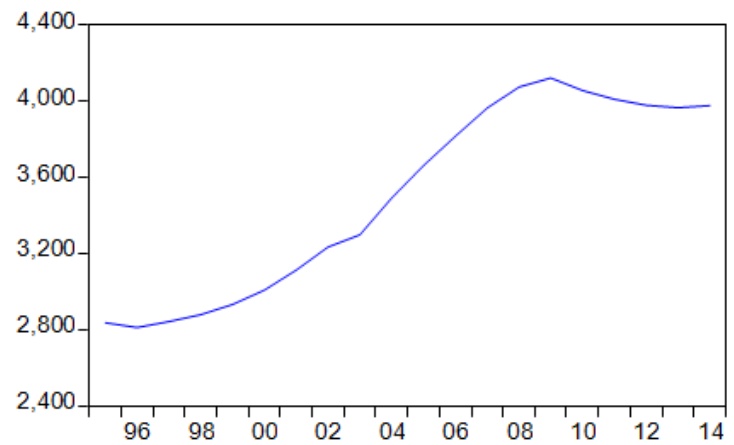

PCHCE

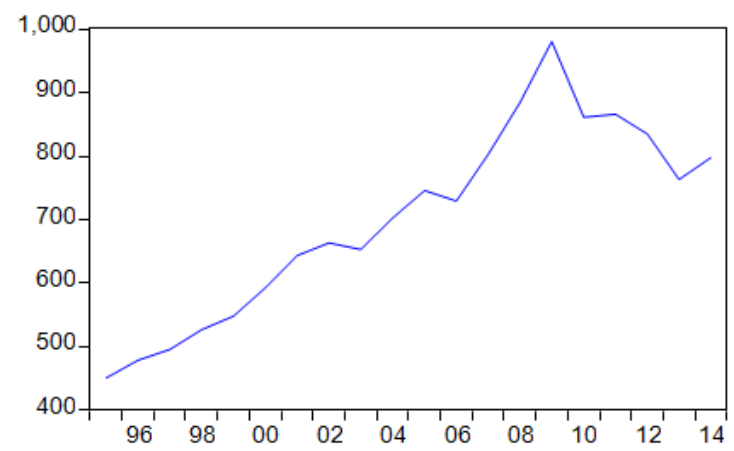

Fig. 1. Time Series Plot of PCHCE and PCGDP

Table 2. Descriptive statistics for PCHCE and PCGDP

\begin{tabular}{llc}
\hline Statistics & PCGDP & PCHCE \\
\hline Mean & 3502.363 & 700.9048 \\
Median & 3575.711 & 715.7172 \\
Maximum & 4120.396 & 980.2639 \\
Minimum & 2809.926 & 450.6589 \\
Standard deviation & 506.1488 & 151.4339 \\
Skewness & -0.164510 & -0.070710 \\
Kurtosis & 1.338916 & 1.994383 \\
Observations & 20 & 20 \\
\hline & & \\
Table 3. Results of KPSS test & Levels & $1^{\text {st }}$ differences \\
\hline Variables & $0.534^{* *}$ & 0.236 \\
PCHCE & $0.554^{* *}$ & 0.176 \\
PCGDP & & \\
\hline
\end{tabular}

Note: $* * * * *, *$ denotes significance at 1,5 and $10 \%$ levels respectively

Table 4. Johansen co-integration test

\begin{tabular}{lcc}
\hline $\mathrm{H}_{0}$ & Trace statistics & Max-Eigen statistic \\
\hline$r=0$ & $21.123^{* *}$ & 13.616 \\
$r \leq 1$ & 7.507 & 7.507 \\
\hline
\end{tabular}

Note:***,*** means significance at 1,5 and $10 \%$ levels, respectively

Table 5. Vector error correction model

\begin{tabular}{lcc}
\hline Variables & D(PCHCE) & D(PCGDP) \\
\hline CointEq1 & -0.454225 & -0.464173 \\
D(PCHEA(-1) & -0.147623 & -0.261912 \\
D(PCGDP(-1) & 0.323999 & 0.857769 \\
C & -0.076458 & 15.48120 \\
\hline
\end{tabular}

Table 6 . The results of specification tests

\begin{tabular}{llc}
\hline Specification test & $\mathrm{H}_{0}$ & Statistics \\
\hline VEC residual serial correlation LM test & No serial correlation at lag order h & 3.006 \\
VEC residual heteroskedasticity test & Residuals are homoskedastic & 21.222 \\
VEC residual normality test & Residuals are multivariate normal & $18.676^{* *}$ \\
\hline Note: $* * *, * *,{ }^{*}$ denotes significance at 1,5 and $10 \%$ levels respectively & \\
Table 7. Pair-wise granger causality test using VECM model & $x^{2}$ statistic & Casual inference \\
\hline Null hypothesis & $3.738^{* *}$ & Causality \\
\hline PCGDP does not granger cause PCHCE & 1.357 & No causality \\
\hline
\end{tabular}

Note: $* * *, * * *$ means significance at 1,5 and $10 \%$ levels, respectively 
Next the analyses continue by executing the pair wise Granger causality tests in the VECM specification. Results in Table 7 shows that there exists a unidirectional causality where PCGDP Granger causes PCHCE. Whereas the reverse causality, PCHCE does not Granger causes PCGDP.

Next the analyses continue by executing the pair wise Granger causality tests in the VECM specification. Results in Table 7 indicate that there exists a unidirectional causality where PCGDP Granger causes PCHCE. Whereas the reverse causality, PCHCE does not Granger causes PCGDP.

\section{Discussion}

The present study estimated the relationship between real per capita GDP and real per capita health care spending for Jordan during 1995 through 2014. The study found a unidirectional causality moving from per capita gross domestic product to per capita health care expenditures. This implies that household sector when they start to have income and subsequent income increments occurs; they have more accessibility to healthcare providers, i.e., clinics, hospitals and to use more healthcare services leading eventually to a higher healthcare expenditures.

The unidirectional causality found in the case of Jordan as an upper middle income country (The World Bank, 2016) is in consistent with results found in lowand middle-income countries as in Erdil and Yetkiner (2009) and for a 10 countries in Economic Cooperation Organization (ECO), Samadi and Homaie (2013) pointed out for a long term relationship between and GDP per capita and health expenditures per capita. The above results stands true in 33 OECD countries where government share in GDP is a potent explanatory variable for Health Care Expenditure (HCE) growth as mentioned in Jochen and Jan-Egbert (2014). In Turkey, Kiymaz et al. (2006) showed a one-way causality moving from per capita gross domestic product to various definitions of health care expenses and a study among Middle East and North Africa region emphasized economic growth Grange causes out-of-pocket health costs according to Akhmat et al. (2014). Therefore, for policy makers they can induce growth in GDP that will eventually raise HCE growth. From a macroeconomic policy, it can target increase in the growth of real wages or increase labour productivity which will increase HCE.

For Jordan, income elasticity was found to be less than 1 , that is health care expenditure is a necessary good, which is in contradiction to Newhouse (1977) study for 13 of developed countries, with Moscone and Tosetti (2010) for the US, with Kiymaz et al. (2006) for Turkey and with Okunade and Murthy (2002). Where the reverse is true as found in Samadi and Homaie (2013) for ECO countries, with Abbas and Hiemenz (2013) for Pakistan. This implies that the demand for health care services is rising less than proportionate to income. In other words, if income increases by $1 \%$ the demand for health care services increases by less than $1 \%$. This is due to the fact that $55 \%$ of the population in Jordan are insured mainly by Ministry of Health $(\mathrm{MoH})$, Royal Medical Services (RMS), the private sector and United Nations Relief and Works Agency UNRWA (DS, 2016).

\section{Concluding Remarks}

In this study we have used Garner casualty approach to investigate the association between per capita health expenditure and per capita GDP for Jordan. We find a one way-directional Granger-causality moving from PCGDP to PCHCE as the leading type of causality for Jordan. That means households with high incomes tend to spend more on health care. This finding is somewhat in tendency with Erdil and Yetkiner (2009; Kiymaz et al., 2006; Magazzino and Mele, 2012; Jochen and Jan-Egbert, 2014; Samadi and Homaie, 2013; Akhmat et al., 2014) and with Mehrara and Musai (2011). An implication of this finding is that Jordan would be successful in their public policies and programmes to create a conductive environment for economic growth and in raising GDP. This may in the end improve the well-being of the population in the long run. In addition, we estimated the income elasticity of health spending and were less than 1during study period. That is, the percentage increase in Increase in health care spending (in percentage) is less that increase in income (measured in percentages too). This implies that health care spending (both public and private) can be characterized as a necessity in Jordan.

\section{Acknowledgment}

The author would like to thank the Deanship of Scientific Research at the Hashemite University for the support.

\section{Author's Contributions}

Rasha M.S. Istaiteyeh: Data collection, Write up, Review.

Mohd Tahir Ismail: Methodology, Review.

\section{Ethics}

This manuscript is original and contains unpublished materials. The author have no conflicts of interest in the development and publication of current research.

\section{References}

Abbas, F. and U. Hiemenz, 2013. What determines public health expenditures in Pakistan? Role of income, urbanization and unemployment. Econom. Change Restructur., 46: 341-362. DOI: $10.1007 / \mathrm{s} 10644-012-9130-7$ 
Akhmat, G., K. Zaman, T. Shukui, J. Yasir and S.R. Khan, 2014. Social health indicators and economic growth: Evidence from East Asia and Pacific, Middle East and North Africa, South Asia and Sub-Saharan Africa. Social Indicators Res., 119: 663-686. DOI: $10.1007 /$ s1 1205-013-0538-x

Amiri, A. and B. Ventelou, 2012. Granger causality between total expenditure on health and GDP in OECD: Evidence from the Toda-Yamamoto approach. Econom. Lett., 116: 541-544. DOI: $10.1016 /$ j.econlet.2012.04.040

Barros, P.P., 1998. The black box of health care expenditure growth determinants. Health Econom., 7: 533-544. PMID: 9809710

CIA, 2016. The World fact Book. Central Intelligence Agency, Jordan.

Devlin, N. and P. Hansen, 2001. Health care spending and economic output: Granger causality. Applied Econom. Lett., 8: 561-564. DOI: 10.1080/13504850010017357

Dritsakis, N., 2005. Health expenditures and gross domestic product an empirical analysis for member-countries of European Union with cointegration analysis. J. Social Sci., 1: 66-71. DOI: 10.3844/jssp.2005.66.71

DS, 2016. Population census 2015. Department of Statistics, The Hashemite Kingdom of Jordan.

Engle, R.F. and C.W.J. Granger, 1987. Co-integration and error correction: Representation, estimation and testing. Econometrica, 55: 251-276. DOI: 10.2307/1913236

Erdil, E. and H.I. Yetkiner, 2009. The Granger-causality between health care expenditure and output: A panel data approach. Applied Econom., 41: 511-518. DOI: 10.1080/00036840601019083

Esteve, V. and J.L. Martinez-Zahonero, 2007. Testing the long-run relationship between health expenditures and GDP in the presence of structural change: The case of Spain. Applied Econom. Lett., 14: 271-276. DOI: 10.1080/13504850500425196

Hansen, P. and A. King, 1996. The determinants of health care expenditure: A cointegration approach. J. Health Econom., 15: 127-137. DOI: 10.1016/0167-6296(95)00017-8

Jochen, H. and S. Jan-Egbert, 2014. Robust determinants of health care expenditure growth. Applied Econom., 46: 4455-4474. DOI: 10.1080/00036846.2014.964829

Johansen, S. and K. Juselius, 1990. Maximum likelihood estimation and inference on cointegration-with applications to the demand for money. Oxford Bull. Econom. Stat., 52: 169-210. DOI: $10.1111 /$ j.1468-0084.1990.mp52002003.X

Johansen, S., 1988. Statistical analysis of cointegration vectors. J. Econom. Dynam. Control, 12: 231-254. DOI: 10.1016/0165-1889(88)90041-3
Jordinvest, 2012. The jordanian health sector. Jordan Investment Trust, Sector report.

Kiymaz, H., Y. Akbulut and A. Demir, 2006. Tests of stationarity and cointegration of health care expenditure and gross domestic product: An application to Turkey. Eur. J. Health Econom., 7: 285-289. DOI: 10.1007/s10198-006-0375-9

Kumar, S., 2013. Systems GMM estimates of the health care spending and GDP relationship: A note. Eur. J. Health Econom., 14: 503-506. DOI: $10.1007 / \mathrm{s} 10198-012-0394-7$

Kwiatkowski, D., P.C.B. Phillips, P. Schmidt and Y. Shin, 1992. Testing the null hypothesis of stationarity against the alternative of a unit root: How sure are we that economic time series have a unit root? J. Econometrics, 54: 159-178.

Lago-Peñas, S., D. Cantarero-Prieto and C. Blázquez-Fernández, 2013. On the relationship between GDP and health care expenditure: A new look. Econom. Modell., 32: 124-129.

DOI: 10.1016/j.econmod.2013.01.021

Leu, R., 1986. The Public-Private Mix and International Health Care Cost, in Public and Private Health Services. In: The Public Private Mix of Health Services, Culyer, A.J. and B. Jonsson (Eds.), Basil Blackwell, Oxford, pp: 41-66.

Magazzino, C. and M. Mele, 2012. The determinants of health expenditure in Italian regions. Int. J. Econom. Finance, 4: 61-72. DOI: 10.5539/ijef.v4n3p61

Mehrara, M. and M. Musai, 2011. Granger causality between health and economic growth in oil exporting countries. Interdisciplinary J. Res. Bus., 1: 103-108.

Moscone, F. and E. Tosetti, 2010. Testing for error cross section independence with an application to US health expenditure. Regional Sci. Urban Econom., 40: 283-291. DOI: 10.1016/j.regsciurbeco.2009.08.004

Mushkin, S.J., 1962. Health as an investment. J. Political Economy, 70: 129-157. DOI: 10.1086/258730

Newhouse, J., 1977. Medical-care expenditure: A crossnational survey. J. Hum. Resources, 12: 115-125. DOI: $10.2307 / 145602$

Okunade A.A. and V.N.R. Murthy, 2002. Technology as a 'major driver' of health care costs: A cointegration analysis of the Newhouse conjecture. J. Health Econom., 21: 147-159. DOI: $10.1016 / \mathrm{S} 0167-6296(01) 00122-9$

Parkin, D., A. McGuire and B. Yule, 1987. Aggregate health care expenditures and national income: Is health care a luxury good? J. Health Econom., 6: 109-127. DOI: 10.1016/0167-6296(87)90002-6

Posnett, J. and T. Hitiris, 1992. The determinants and effects of health expenditure in developed countries. J. Health Econom., 11: 173-181. DOI: 10.1016/0167-6296(92)90033-W 
Samadi, A. and R.E. Homaie, 2013. Determinants of healthcare expenditure in Economic Cooperation Organization (ECO) Countries: Evidence from panel cointegration tests. Int. J. Health Policy Manage., 1: 63-68. DOI: 10.15171/ijhpm.2013.10
The World Bank, 2016. Jordan/Data The World Bank. Wang, K.M., 2011. Health care expenditure and economic growth: Quantile panel-type analysis. Econom. Modell., 28: 1536-1549.

DOI: $10.1016 / \mathrm{j}$.econmod.2011.02.008 